\title{
МОРФОЛОГІЧНІ ЗМІНИ СТРУКТУР СКРОНЕВО-НИЖНЬОЩЕЛЕПНИХ СУГЛОБІВ ПРИ ЕКСПЕРИМЕНТАЛЬНІЙ ГІПЕРГЛІКЕМІЇ
}

\author{
๑Л. В. Рубас, М. С. Гнатюк \\ Тернопільський національний медичний університет імені І. Я. Горбачевського МОЗ України
}

РЕзЮМЕ. Поширеність цукрового діабету, його ускладнень, а також захворювань скронево-нижньощелепних суглобів невпинно зростає. Однак немає даних про зміни структури цього диартрозу при вказаній ендокринній патології.

Мета - встановити особливості структурних змін скронево-нижньощелепного суглоба при гіперглікемії.

Матеріал і методи. Експериментально вивчено скронево-нижньощелепні суглоби 60 білих статевозрілих щурів-самців, яких поділили на 4 групи. Тваринам 1 та 2 груп моделювали стрептозотоцин-індукований цукровий діабет. Самців 3 та 4 груп використовували у якості контролю. Евтаназію щурів здійснювали через 30 та 60 діб від початку експерименту шляхом кровопускання в умовах тіопенталового наркозу. Гістологічні зрізи із скроневонижньощелепних суглобів готували за загальноприйнятою методикою, розміщували на предметних скельцях, фарбували гематоксиліном-еозином та вивчали світлооптично.

Результати. Товщина перихондрію дещо стоншувалась, переважно у клітинному шарі. В прилеглих судинах наростало повнокров'я. Частина великих клітин із ексцентрично розташованими більш чіткими ядрами локалізувалась переважно по периферії, синтезуючи навколо себе матрикс. По краю трабекул візуалізувалась помірна кількість остеобластів. У внутрішньосуглобовому диску спостерігався помірний мукоїдний набряк. Його волокна дещо потовщувались, зростала кількість клітинного інфільтрату між ними, з переважанням фібробластів, макрофагів та опасистих клітин. У синовіальній оболонці наростала вогнищева гіперплазія клітин та посилювався синтез синовіальної рідини. Серед товстих волокон еластину зв'язкового апарату збільшувалась кількість тонких колагенових волокон із набряком та помірною клітинною реакцією.

В оточуючій тканині візуалізувались пучки колагенових волокон, між якими накопичувались фіброцити, а також ознаки осифікації. Зростання кількості остеобластів у волокнистій структурі та деструктивні зміни хондроцитів свідчили про ознаки руйнування хрящової тканини. Серед волокон кісткових трабекул спостерігалась вогнищева гіперплазія клітин гемопоетичного ряду. В трабекулах візуалізувалась велика кількість капілярних петель. Кровонаповнення судин знижувалось. Дозрівання хондроцитів, їхнє перетворення з клітин першого в клітини другого типу призводило до зростання базофілії міжклітинної речовини. У внутрішній поверхні суглоба між клітинами фібробластичного ряду візуалізувались остеобласти.

Висновки. Експериментальний стрептозотоцин-індукований цукровий діабет призводив до виражених деструктивних процесів у скронево-нижньощелепних суглобах. Встановлені морфологічні зміни структурних елементів даного суглоба свідчать про порушення процесів остео- та хондросинтезу через 2 місяці від початку експериментального моделювання гіперглікемії.

КЛючовІ СлОВА: диартроз; скронево-нижньощелепний суглоб; стрептозотоцин-індукований цукровий діабет; гіперглікемія.

Вступ. В останні десятиліття по всьому світу невпинно зростає кількість людей з цукровим діабетом (ЦД) [1]. Згідно з даними Всесвітньої організації охорони здоров'я, на 2000 рік відзначалось 175,4 млн хворих з цим діагнозом, а вже на 2017 рік їх численність становила понад 425 млн, серед них тільки 68 млн - люди, старші 65 років, та понад $1 \mathrm{млн} \mathrm{-} \mathrm{повнолітні} \mathrm{особи} \mathrm{з} \mathrm{ЦД} \mathrm{1-го} \mathrm{типу,} \mathrm{які} \mathrm{не} \mathrm{до-}$ сягли 20 років. Учені Міжнародної федерації діабету прогнозують, що станом на 2045 рік показник хворих на ЦД підніметься до позначки 629 млн [2]. Не менш критичною $є$ ситуація зі зростанням даного захворювання та його ускладнень і в нашій країні. Центр медичної статистики МОЗ України в 2017 році зафіксував 2757,7 млн осіб із ЦД. Однак, у зв'язку з прихованими формами ЦД, кількість хворих в Україні в 2-3 рази вища від вищезазначеної. Прогресуючий ріст кількості хворих та значний ризик виникнення ускладнень дає змогу стверджувати, що ЦД $є$ медико-соціальною проблемою не лише в Україні, а й у всьому світі $[3,4]$. Поряд з цим, захворювання скронево-нижньощелепного суглоба (СНЩС) займає провідне місце серед патологій щелепно-лицевої ділянки [5]. Поширеність ознак і симптомів розладів СНЩС $€$ високою і коливається від 16 до 88 \% населення [6]. Однак наукова література не містить інформації щодо змін структурних компонентів диартрозу при цукровому діабеті.

Мета - встановити особливості структурних змін скронево-нижньощелепного суглоба щурів при гіперглікемії.

Матеріал і методи дослідження. Дослідження було виконано на базі центральної науково-дослідницької лабораторії Тернопільського національного медичного університету імені І. Я. Горбачевського МОЗ України. Всі експерименти проводилися згідно з умовами та правилами біо- 
Огляди літератури, оригінальні дослідження, погляд на проблему, випадок з практики, короткі повідомлення етики, передбаченими «європейською конвенцією про захист хребетних тварин, які використовуються для експериментів та інших наукових цілей», «Загальними етичними принципами експериментів на тваринах" та Гельсинською декларацією Генеральної асамблеї Всесвітньої медичної асоціації.

Експериментальне дослідження здійснено на 60 білих статевозрілих щурах-самцях масою 180-200 г, яких утримували на раціоні віварію. Тварин поділили на 4 групи по 15 щурів в кожній. Самцям 1 та 2 груп моделювали цукровий діабет. Період спостереження за даними тваринами тривав 30 та 60 діб відповідно. Щурів 3 та 4 груп використовували у якості контролю у відповідні терміни дослідження. Інсулінозалежний ЦД у щурів викликали шляхом одномоментного введення стрептозотоцину «Sigma» внутрішньочеревинно у розрахунку 50 мг/кг [7].

Евтаназію тварин здійснювали через 1 та 2 місяці від початку експерименту шляхом кровопускання в умовах тіопенталового наркозу.

Гістологічні зрізи готували із СНЩС за загальноприйнятою методикою, розміщували на предметних скельцях, фарбували гематоксиліномеозином та вивчали за допомогою мікроскопів Люмам P-8 та МБИ-15 [8]. Для фотодокументування зображення з гістологічних препаратів виводили на монітор комп'ютера за допомогою мікроскопа Delta Optical та цифрової відеокамери (Digital Camera SCMOS) за допомогою програмного забезпечення ТоupWier при різних збільшеннях.

Результати й обговорення. Скронево-нижньощелепний суглоб - складне анатомічне утворення, яке забезпечує різноманітні рухи нижньої щелепи. Він складається 3 нижньощелепної та скроневої кісток, а саме головки нижньої щелепи, ямки та суглобного горбика скроневої кістки, внутрішньосуглобного диска та суглобової капсули. Допоміжний апарат цього суглоба включає зв'язки, які фіксують суглобний диск до скроневої кістки та до шийки нижньої щелепи, та оточуючі м'язи.

Гістологічно головка суглоба представлена губчастою кістковою тканиною. Суглобова поверхня покрита шаром гіалінового хряща - перихондрієм. Внутрішня поверхня сполучнотканинної вистилки повернута до вільного суглобового простору, вкрита синовіальною оболонкою, яка продукує синовіальну рідину.

У порожнині суглоба між головкою нижньої щелепи та ямкою скроневої кістки залягає внутрішньосуглобовий диск у вигляді двояко вигнутої хрящової пластинки. Він повторює форму зверху переднього відділу нижньощелепної ямки, знизу - головки нижньої щелепи. Структурно складається із грубоволокнистої сполучної тканини із незначною кількістю клітинних елементів. У цент-

ральних шарах пучки колагену розташовуються більш рихло, ніж у периферичних. Поряд із колагеновими волокнами візуалізуються звивисті тонкі еластичні волокна. Диск об'єднаний із капсулою суглоба ділянкою рихлої сполучної тканини, багатої на судини та нерви. Зовнішній шар містить у собі колагенові та еластичні волокна, нерви та судини. Синовіальна поверхня представлена покривним та камбіальними шарами, під якими розташована судинна сітка. Судини звичайної структури. Субхондральна губчаста кістка складається із трабекул звичайної структури та помірно розширених резорбційних порожнин, в яких візуалізується волокнистий кістковий мозок з різною кількістю та щільністю мононуклеарних клітинних інфільтратів, моноцитів та лімфоцитів, що відображає певний ступінь його активності.

Через 1 міс. після моделювання цукрового діабету встановлені зміни у структурах суглоба. Гістологічно головка суглоба структурно змінювалась. Товщина перихондрію незначно зросла за рахунок помірного збільшення розмірів його клітин. В свою чергу, товщина гіалінового хряща дещо збільшувалася за рахунок помірної гіперплазії хондроцитів та їх підвищеної проліферації. Також хондроцити візуалізувались у товщі губчастої речовини кістки, що може свідчити про прояви метаплазії у тканині. Трабекули субхондальної губчастої кістки дещо стоншувались, площа порожнин візуально збільшувалась, зустрічались ділянки із гіперплазією клітин кісткового мозку. В окремих ділянках хрящова тканина межувала із просвітами порожнин.

Зі сторони внутрішньої поверхні сполучнотканинної вистилки спостерігається посилення набряку, в тому числі колагенових волокон, у поєднанні із клітинною інфільтрацією та поширенням набряку на оточуючу тканину.

У грубоволокнистій тканині збільшується кількість клітинного компонента, представленого переважно лімфо- та гістіоцитарним рядом, посилюється набряк волокон, дещо збільшується кількість звивистих тонких еластичних волокон. У колагенових волокнах диска також спостерігаються збільшення набряку, початкові прояви мукоїдного набряку волокон, з'являються поодинокі помірно розширені судини, збільшується периваскулярний набряк.

Через 2 місяці від початку експерименту структура суглоба зазнавала таких змін. Товщина перихондрію дещо стоншувалася, переважно у клітинному шарі. В прилеглих судинах наростало повнокров'я, стінки судин із мукоїдним набряком. Частина великих клітин із ексцентрично розташованими більш чіткими ядрами локалізувалась переважно по периферії, синтезуючи навколо себе 
Огляди літератури, оригінальні дослідження, погляд на проблему, випадок з практики, короткі повідомлення матрикс, який насичувався органічними речовинами і на якому накопичувалися солі кальцію. По краю трабекул візуалізувалась помірна кількість остеобластів. Переважна більшість хондроцитів залишилась без ознак кальцифікації.

У внутрішньосуглобовому диску спостерігався помірний мукоїдний набряк. Його волокна дещо потовщувалися, зростала кількість клітинного інфільтрату між ними, серед яких переважали фібробласти, макрофаги та опасисті клітини. В синовіальній оболонці наростала вогнищева гіперплазія клітин та посилювався синтез синовіальної рідини. Серед товстих волокон еластину зв'язкового апарату збільшувалася кількість тонких колагенових волокон із набряком та помірною клітинною реакцією.

В оточуючій тканині візуалізувались пучки колагенових волокон, між якими накопичувались фіброцити, з'явились волокна із ознаками осифікації. Зростання кількості остеобластів у волокнистій структурі та деструктивні зміни хондроцитів свідчили про ознаки руйнування хрящової тканини. Серед волокон в кісткових трабекулах мала місце вогнищева гіперплазія клітин гемопоетичного ряду.

У субхондральній частині кістки спостерігалось зменшення площі порожнин гемопоезу, стоншання та пошкодження кісткових пластинок, формувались порожнини резорбції, збільшувалась кількість остеокластів в ендості, що посилю-

вало демінералізацію кісткового матриксу. В трабекулах візуалізувалась велика кількість капілярних петель. Подекуди спостерігалась вогнищева гіперплазія хондроцитів із новоутворенням ізогенних груп клітин. В окремих колагенових волокнах відзначалось накопичення солей кальцію. Кровонаповнення судин знижувалось.

Дозрівання хондроцитів, їхнє перетворення з клітин першого типу в клітини другого типу призводило до посилення синтезу протеогліканів і, відповідно, до зростання базофілії міжклітинної речовини. У внутрішній поверхні суглоба серед клітин фібробластичного ряду візуалізувались остеогенні клітини (остеобласти), про що свідчать утворення ліній цементування.

Висновки. Експериментальний стрептозотоцин-індукований цукровий діабет призводив до виражених деструктивних процесів у скроневонижньощелепних суглобах. Установлені морфологічні зміни структурних елементів цього суглоба свідчать про порушення процесів остео- та хондросинтезу через 2 місяці від початку експериментального моделювання гіперглікемії.

Перспективи подальших досліджень. Знання анатомічних особливостей структур скроневонижньощелепного суглоба, а також динаміки їх перебудови при експериментальній гіперглікемії дозволять покращити діагностику, профілактику та корекцію досліджуваної патології.

\section{ЛІТЕРАТУРА}

1. Kolesnyk Yu. M. Current methods of the modeling of experimental diabetes mellitus type 2: a literature review / Yu. M. Kolesnyk // Патологія. -2016. - №1. - С. 10-14.

2. Камінський О. В. Огляд сучасних рекомендацій 3 лікування цукрового діабету 2-го типу / О. В. Камінський // Ліки України. - 2021. - № 2 (248). - С. 7-12.

3. Лукашевич П. Ю. Сучасні підходи до забезпечення цукрознижувальною терапією хворих на цукровий діабет в Україні / П. Ю. Лукашевич, В. Л. Орленко, М. Д. Тронько // Ендокринологія. - 2017. - Т. 22, № 1. С. $45-50$.

4. Стандарти надання медичної допомоги хворим на цукровий діабет медичною сестрою загальної практики / N. I. Reha, A. V. Vasilenko, O. R. Reha, Z. H. Zolotyi // Медсестринство. - 2019. - № 1. - Р. 8-12.

5. Макєєв В. Ф. Порівняльний аналіз клінічних ознак в осіб з підтвердженим і непідтвердженим діаг- нозом скронево-нижньощелепних розладів // В. Ф. Макєєв, О. Д. Телішевська, М. Ю. Михайлевич // Сучасна стоматологія. - 2020. - №1. - Р. 103.

6. Diagnosis of temporomandibular joint disorders: indication of imagine exams / A. F. Luciano, E. Grossman, E. Januzzi, [et al.] // Braz. J. Otorhinolaryngol. - 2016. Vol. 82 (3). - P. 342

7. Ганчев К. С. Характеристика стану вродженої ланки місцевого імунітету тканин пародонту щурів після екстракції зубу на фоні цукрового діабету за показниками експресії CD 68 / К. С. Ганчев // Актуальні проблеми сучасної медицини: вісник української медичної стоматологічної академії. - 2019. - Т. 19, вип. 1 (65). С. 52-56.

8. Методики морфологічних досліджень : монографія / М. М. Багрій, В. А. Діброва, О. Г. Попадинець, І. М. Грищук. - Вінниця : Нова книга, 2016. - 238 с. 
Огляди літератури, оригінальні дослідження, погляд на проблему, випадок з практики, короткі повідомлення REFERENCES

1. Kolesnyk, Yu.M. (2016). Current methods of the modeling of experimental diabetes mellitus type 2: a literature review. Patolohia - Pathology, 1, 10-14.

2. Kaminskyy, O.V. (2021). Ohliad suchasnykh rekomendatsiy z likuvannia tsukrovogo diabetu 2-go typu [Review of modern recommendations for the treatment of type 2 diabetes mellitus]. Liky Ukrainy - Medicines of Ukraine, 2 (248), 7-12 [in Ukrainian].

3. Lukashevich, P.Yu., Orlenko, V.L., \& Tronko, M.D. (2017) Suchasni pidkhody do zabezpechennia tsukroznyzhuvalnoiu terapiieiu khvorykh na tsukrovyy diabet $v$ Ukraini [Modern approaches to providing sugar-lowering therapy to patients with diabetes mellitus in Ukraine]. Endokrynolohiia - Endocrinology, 22, 1, 45-50 [in Ukrainian].

4. Reha, N.I., Vasilenko, A.V., Reha, O.R., \& Zolotyi, Z.H. (2019). Standarty nadannia medychnoi dopomohy khvorym na tsukrovyi diabet medychnoiu sestroiu zahalnoi praktyky [Standards of providing medical care to patients with diabetes by a nurse of general practice]. Medsestrynstvo - Nursing, 1, 8-12 [in Ukrainian].

5. Makeev, V.F., Telishevskaya O.D., \& Mikhailevich, M.Yu. (2020). Porivnialnyi analiz klinichnykh oznak v osib z pidtverdzenym i nepidtverdzenym diagnozom skro-

nevo-nyzhnioshchelepnykh rozladiv [Comparative analysis of clinical signs in persons with confirmed and unconfirmed diagnosis of temporomandibular disorders]. Suchasna stomatolohia - Modern Dentistry, 1. 103 [in Ukrainian].

6. Luciano, A.F. Grossman, E., Januzzi, E., Queiroz de Paula, M.V., \& Pires Carvalho, A.C. (2016). Diagnosis of temporomandibular joint disorders: indication of imagine exams. Braz. J. Otorhinolaryngol., 82 (3), 342.

7. Ganchev, K.S. (2019). Kharakterystyka stanu vrodzenoi lanky mistsevoho imunitetu tkanyn parodontu shchuriv pislia ekstraktsii zubu na foni tsukrovoho diabetu za pokaznykamu ekspresii CD 68 [Characteristics of the state of congenital local immunity of periodontal tissues of rats after tooth extraction on the background of diabetes mellitus on the expression of CD 68] Aktualni problemy suchasnoi medytsyny: visnyk ukrainskoi medychnoi stomatolohichnoi akademii - Actual Problems of Modern Medicine: Bulletin of the Ukrainian Medical Dental Academy, 19, 1 (65). 52-56 [in Ukrainian].

8. Bagriy, M.M. (2016). Methodyka morfologichnykh doslidzen: monografia [Methods of morphological research: monograph]. Vinnytsia: Nova Knyha [in Ukrainian].

\title{
МОРФОЛОГИЧЕСКИЕ ИЗМЕНЕНИЯ СТРУКТУР ВИСОЧНО-НИЖНЕЧЕЛЮСТНЫХ СУСТАВОВ ПРИ ЭКСПЕРИМЕНТАЛЬНОЙ ГИПЕРГЛИКЕМИИ
}

ФЛ. В. Рубас, М. С. Гнатюк

\author{
Тернопольский национальный медицинский университет имени И. Я. Горбачевского Моз Украины
}

РЕЗЮМЕ. Распространенность сахарного диабета, его осложнений, а также заболеваний височно-нижнечелюстного сустава постоянно растет. Однако нет данных об изменениях структуры этого диартроза при данной эндокринной патологии.

Цель - установить особенности структурных изменений височно-нижнечелюстного сустава при гипергликемии.

Материал и методы. Экспериментально изучены височно-нижнечелюстные суставы 60 белых половозрелых крыс-самцов, которых поделили на 4 группы. Животным 1 и 2 групп моделировали стрептозотоцин-индуцированный сахарный диабет. Самцов 3 и 4 групп использовали в качестве контроля. Эвтаназию крыс осуществляли через 30 и 60 дней от начала эксперимента путем кровопускания в условиях тиопенталового наркоза. Гистологические срезы с височно-нижнечелюстных суставов готовили по общепринятой методике, размещали на предметных стеклах, окрашивали гематоксилином-эозином и изучали светооптически.

Результаты. Толщина перихондрия несколько истончалась, преимущественно в клеточном слое. В прилегающих сосудах нарастало полнокровие. Часть крупных клеток с эксцентрично расположенными более четкими ядрами локализовалась преимущественно по периферии, синтезируя вокруг себя матрикс. По краю трабекул визуализировалось умеренное количество остеобластов. Во внутрисуставном диске наблюдался умеренный мукоидный отек. Его волокна несколько утолщались, росло количество клеточного инфильтрата между ними, с преобладанием фибробластов, макрофагов и тучных клеток. В синовиальной оболочке нарастала очаговая гиперплазия клеток и усиливался синтез синовиальной жидкости. Среди толстых волокон эластина связочного аппарата увеличивалось количество тонких коллагеновых волокон с отеком и умеренной клеточной реакцией.

В окружающей ткани визуализировались пучки коллагеновых волокон, между которыми накапливались фиброциты, а также признаки осификации. Рост количества остеобластов в волокнистой структуре и деструктивные изменения хондроцитов свидетельствовали о признаках разрушения хрящевой ткани. Среди волокон костных трабекул наблюдалась очаговая гиперплазия клеток гемопоэтического ряда. В трабекулах визуализировалось большое количество капиллярных петель. Кровенаполнение сосудов снижалось. Созревание хондроцитов, их превращение из клеток первого в клетки второго типа, приводило к росту базофилии межклеточного вещества. Во внутренней поверхности сустава между клетками фибробластического ряда визуализировались остеобласты.

Выводы. Экспериментальный стрептозотоцин-индуцированный сахарный диабет приводил к вираженным деструктивным процессам в височно-нижнечелюстных суставах. Выявленные морфологические изменения 
Огляди літератури, оригінальні дослідження, погляд на проблему, випадок з практики, короткі повідомлення структурных элементовв данного сустава свидетельствуют о нарушенни процессов остео- та хондросинтеза через 2 месяца от начала экспериментального моделирования гипергликемии.

КЛЮЧЕВЫЕ СЛОВА: диартроз; височно-нижнечелюстной сустав; стрептозотоцин-индуцированный сахарный диабет; гипергликемия.

\section{MORPHOLOGICAL CHANGES IN THE STRUCTURES OF THE TEMPOROMANDIBULAR JOINTS IN EXPERIMENTAL HYPERGLYCEMIA}

\section{Horbachevsky Ternopil National Medical University}

SUMMARY. The prevalence of diabetes mellitus, its complications, as well as diseases of the temporomandibular joints is constantly increasing. However, there are no data on changes in the structure of this diarthrosis in this endocrine pathology.

The aim - to determine the peculiarities of structural changes of the temporomandibular joints in hyperglycemia.

Material and Methods. The temporomandibular joints of 60 white adult male-rats, which were divided into 4 groups, were experimentally studied. Streptozotocininduced diabetes mellitus was simulated in animals of groups 1 and 2. Males of groups 3 and 4 were used as controls. Euthanasia of rats was performed 30 and 60 days after the start of the experiment by bloodletting under thiopental anesthesia. Histological sections of the temporomandibular joints were prepared according to conventional methods, placed on slides, stained with hematoxylin-eosin and examined with microscopes.

Results. The thickness of the perichondrium was somewhat thinned mainly in the cell layer. Blood supply grew in the surrounding vessels. Some of the large cells with eccentrically located clearer nuclei, localized mainly on the periphery, synthesizing a matrix around them. A moderate number of osteoblasts were visualized along the edge of the trabeculae. Moderate mucoid edema was observed in the intra-articular disc. Its fibers thickened slightly, the amount of cellular infiltrate between them increased, with a predominance of fibroblasts, macrophages and mast cells. Focal hyperplasia of cells and the synthesis of synovial fluid increased. Among the thick fibers of the ligament, the number of thin collagen fibers with swelling and moderate cellular response increased.

Bundles of collagen fibers were visualized in the surrounding tissue, between which fibrocytes accumulated, as well as signs of ossification. An increase in the number of osteoblasts in the fibrous structure and destructive changes of chondrocytes were indicative of signs of cartilage destruction. Focal hyperplasia of hematopoietic cells was observed among bone trabeculae fibers. A large number of capillary loops were visualized in the trabeculae. Blood supply to the blood vessels decreased. Maturation of chondrocytes, their transformation from cells of the first to cells of the second type, led to growth of basophilia of intercellular substance. Osteoblasts were visualized in the inner surface of the joint between the cells of the fibroblastic row.

Conclusions. Experimental streptozotocin-induced diabetes mellitus led to severe destructive processes in the temporomandibular joints. The revealed morphological changes of structural elements in this joint testify to disturbance of processes of osteotherapy and chondrosynthesis in 2 months from the beginning of experimental modeling of a hyperglycemia.

KEY WORDS: diarthrosis; temporomandibular joint; streptozotocin; streptozotocininduced diabetes mellitus; hyperglycemia.

Отримано 05.04.2021 